\title{
PELATIHAN PEMBUKUAN SEDERHANA BAGI KELOMPOK USAHA EKS PNPM DI KELURAHAN TOAPAYA ASRI KECAMATAN TOAPAYA KABUPATEN BINTAN
}

\section{Simple Accounting Training for PNPM's Former Business Groups In Toapaya Asri Village, Bintan}

\author{
Fatahurrazak $^{1^{*}, \text { Muhammad Idris DM }}{ }^{2}$ \\ ${ }^{1}$ Jurusan Akuntansi, Fakultas Ekonomi Universitas Maritim Raja Ali Haji - Tanjungpinang \\ ${ }^{2}$ Jurusan Manajemen, Fakultas Ekonomi Universitas Maritim Raja Ali Haji - Tanjungpinang
}

Korespondensi : faturajafatur@gmail.com

\begin{abstract}
ABSTRAK
Laporan keuangan berfungsi sebagai alat untuk menganalisis kinerja keuangan yang dapat memberikan informasi tentang posisi keuangan, labarugi dan arus kas, sehingga dapat dijadikan sebagai dasar membuat keputusan-keputusan ekonomi. Pengabdian ini dilaksanakan di Kelurahan Toapaya Asri Kecamatan Toapaya Kabupaten Bintan Provinsi Kepulauan Riau yang diikuti oleh 30 Kelompok Usaha yang dalam bisnis mereka menggunakan dana pinjaman dari UPK (Eks PNPM) Kecamatan Toapaya Kabupaten Bintan. Kelompok usaha ini adalah termasuk yang lancar dalam mengembalikan pinjaman, namun masih belum dapat menyusun laporan keuangan sesuai dengan prinsip akuntansi yang berlaku umum. Pengabdian ini dilaksanakan dalam bentuk pelatihan dan Praktek. Dalam pelatihan ini juga ditambahkan pada penekanan bagaimana cara menghitung harga pokok perunit secara benar dan menentukan penjualan paling minimal untuk menetapkan batas target penjualan agar usaha tidak mengalami kerugian
\end{abstract}

Kata Kunci : Laporan keuangan, pelatihan

\begin{abstract}
The function of financial report is to analyze financial performance that can provide financial position information, profit and loss and cash flow. This activity was carried out in Toapaya Asri Village, Toapaya District, Bintan Regency, Riau Islands Province. The activity was attended by 30 Business Groups that used loan funds from the UPK in the Toapaya area, Bintan Regency. This business group is a group that is on time to repay loans, but still cannot prepare financial statements in accordance with accounting principles. This activity is carried out in the form of training. In this training also added emphasis on how to calculate the basic price and determine the minimum sales to set the target sales limit
\end{abstract}

Keywords: Financial reports, training 


\section{PENDAHULUAN}

Kelompok Usaha Ekonomi Masyarakat yang mandiri merupakan kelompok yang mempunyai tarap yang tertinggi, di mana di dalam kelompok mempunyai administrasi yang bagus dan lengkap, serta mempunyai hubungan terus menerus terhadap kelompoknya, baik informasi maupun pengelolaan usaha, seperti gotong royong setiap minggu untuk membersihkan lahan-lahan pertanian yang mereka kelola hal itu akan dapat menciptakan sikap persaudaraan yang sangat tinggi.

Strategi Peningkatan Adalah cara yang dilakukan dalam sebuah kegiatan untuk membuat perbaikan dalam hal kemakmuran yang dirasakan oleh masyarakat dalam menjalankan usahanya, di mana usaha tersebut dapat meningkatkan taraf hidupnya dari pendapatan usaha yang diperoleh agar kegiatan mereka berjalan dengan lancar.

Upaya penggerakan sumber daya adalah mengembangkan potensi ekonomi masyarakat dalam meningkatkan produktivitas masyarakat, sehingga baik sumber daya manusia maupun sumber daya alam di sekitar dapat dikembangkan dengan maksimal sehingga dibutuhkan produktivitas dalam menjalankan usaha, dengan demikian masyarakat dan lingkungan mampu secara partisipatif menghasilkan dan menumbuhkan nilai tambah yang meningkatkan kemakmuran serta kesejahteraan mereka. Hal itu membutuhkan daya pikir kreatif, masyarakat tidak saja mengerjakan usaha yang mudah-mudah saja tetapi masyarakat harus memikirkan mengelola sumber daya alam dengan menggunakan konsep produksi sehingga hasil yang diperoleh dapat meningkatkan kesejahteraan keluarga.

Kegiatan produksi merupakan kegiatan yang berhubungan dengan penciptaan/pembuatan barang, jasa atau kombinasinya, melalui proses transformasi dari masukan sumber daya produksi menjadi keluaran yang diinginkan. Melalui kegiatan produksi, segala sumber daya masukan perusahaan diintegrasikan untuk menghasilkan keluaran yang memiliki nilai tambah. Produk yang dihasilkan dapat berupa barang atau akhir, barang setengah jadi ataupun jasa. Bagi perusahaan berorientasikan laba, produk ini selanjutnya dijual untuk memperoleh keuntungan dan sumber dana yang baru bagi kegiatan operasi berikutnya. Kegiatan produksi merupakan kegiatan kompleks, tidak saja mencakup pelaksanaan fungsi manajemen dalam mengkordinasikan berbagai kegiatan atau bagian dalam mencapai tujuan produksi, tetapi juga mencakup kegiatan teknis untuk menghasilkan suatu produk yang memenuhi spesifikasi yang diinginkan, dengan proses produksi yang efisien dan efektif serta dengan mengantisipasi perkembangan teknologi dan kebutuhan konsumen di masa yang akan datang. Oleh karena itu, pengetahuan yang baik tentang manajemen produksi perlu dimiliki oleh semua pihak yang terlibat langsung dalam proses pembuatan produk sesuai dengan peranan masing-masing.

Selain untuk memenuhi kebutuhan manusia adalah untuk mendapatkan keuntungan yang layak, maka suatu organisasi dapat mempertahankan hasil produksinya agar berkembang dan maju, untuk mencapai tujuan tersebut setiap masyarakat harus mempelajari konsep produktivitas yang tinggi, yang dalam hal ini akan melibatkan seseorang ketua kelompok untuk berkoordinasi kepada seluruh elemen yang ada untuk mendukung dalam pembentukan produktivitas dan pemasaran.

Meningkatkan Produktivitas dan Pemasaran yang layak memang tak semudah yang kita bayangkan, produkproduk yang dibuat oleh masyarakat harus memiliki standarisasi agar produk 
tersebut dapat diterima di pasar nasional maupun internasional, hal ini menjadi sebuah tantangan bagi pemerintah Kabupaten Bintan khususnya untuk melakukan indentifikasi setiap kelompok Usaha Ekonomi Masyarakat Produktif yang ada di Kabupaten Bintan, untuk dikaji permasalahan yang ada di lapangan di dalam mengembangkan usaha yang mereka jalani, serta memberikan pelatihan-pelatihan dan penguatan bagi kelompok Usaha Ekonomi Masyarakat Produktif agar produksi dan efektifitas kerja mereka dapat berkembang dengan maksimal, sehingga dapat meningkatkan kesejahteraan masyarakat, sesuai dengan visi dan misi Kabupaten Bintan, yaitu terwujudnya Kabupaten Bintan yang Madani dan Sejahtera melalui pencapaian Bintan gemilang 2025.

Adapun kelompok usaha pada program pengabdian masyarakat ini adalah para Kelompok Usaha Eks PNPM di Kelurahan Toapaya Asri - Kecamatan Toapaya yang telah menjalankan usaha lebih dari 4 tahun dengan bentuk usaha yang beraneka macam, seperti usaha kerupuk ikan, warung kelontong, bengkel, perkebunan palawija, tanaman hias, gorengan, menjahit, konter HP/pulsa, dan warung nasi.

Pada awalnya kelompok usaha ini dalam aktifitasnya didanai dari PNPM (Program Nasional Pemberdayaan Masyarakat), dan sejak PNPM tidak diperpanjang lagi pada desember 2014, maka aset PNPM selanjutnya dikelola oleh UPK (Unit Pengelola Kegiatan) sampai saat ini. Adapun sistem kerja penyaluran dana pinjaman ini adalah diberikan dalam bentuk kelompok usaha yang terdiri dari 5-10 orang atau lebih setiap kelompoknya, dan dana pinjaman akan diberikan kepada kelompok dalam jumlah yang sama dengan jangka waktu pengembalian selama 10 bulan - satu tahun dengan tingkat bunga yang rendah. Ketua kelompok bertanggung jawab dalam mengembalikan pinjaman secara keseluruhan dan tidak boleh menunggak, dan biasanya ketua kelompok punya cara sendiri untuk memastikan tidak ada anggota kelompoknya yang mangkir dalam membayar pinjaman mereka, dan UPK biasanya akan memberikan sanksi tertentu apabila ada kelompok yang menunggak dalam melakukan pembayaran, seperti mendahulukan pencairan untuk kelompok yang masuk dalam kategori lancar sebagai penghargaan bagi kelompok tersebut yang juga sering disebut Insentif Pembayaran Tepat Waktu (IPTW).

Kelompok dalam hal ini bukanlah mereka yang menjalankan bisnis yang sama yang tergabung dalam kelompok, namun dibentuk kelompok hanyalah untuk mempermudah kontrol oleh UPK dan sebagai tempat dan sarana berkomunikasi bagi setiap anggota kelompok termasuk bimbingan dan pembinaan yang diberikan, sehingga anggota kelompok ini haruslah mereka tinggal di daerah yang berdekatan sehingga memudahkan untuk berkomunikasi, walaupun bisnis yang mereka jalankan tidak sama.

Selain itu tanggungjawab terhadap dana yang dipinjamkan dari UPT adalah tanggungjawab setiap anggota kelompok yang meminjam, walaupun demikian apabila ada salah satu anggota kelompok yang gagal dalam membayar angsuran pinjaman, maka itu dianggap kegagalan kelompok, dan jika sekali saja kelompok gagal atau terlambat dalam membayar angsuran maka sudah termasuk pada kategori tidak lancar sehingga akan mengganggu untuk pencairan pada periode berikutnya.

Berdasarkan hasil survey yang dilakukan terhadap kelompok usaha yang masuk dalam kategori lancar (IPTW) ternyata kelompok tersebut sebagian besar tidak menyelenggarakan pencatatan apalagi membuat pembukuan yang benar sehingga sangat sulit untuk mengukur dan mengetahui apakah usaha yang dijalankan memberikan keuntungan atau kerugian. Bagi mereka dari hasil penjualan atau jasa 
yang diberikan sudah dapat menutupi angsuran hutang dan kebutuhan seharihari, itu sudah dianggap berhasil dan mencukupi kebutuhan primer. Akibatnya pengembangan usaha ke arah yang lebih besar akan sangat sulit untuk diwujudkan, dan ditambah lagi dengan tidak adanya membuat perencanaan untuk mengembangkan usahanya.

Hal yang tidak kalah pentingnya yang selalu dilanggar adalah para pelaku usaha ini tidak menerapkan konsep entitas, yaitu memisahkan memisahkan antara aset perusahaan dengan aset pribadi, dan yang terjadi adalah di mana aset perusahaan juga adalah aset pribadi sehingga akan sangat sulit dalam penyusunan laporan keuangan termasuk kesulitan dalam menghitung harga pokok produksi secara benar karena asset usaha masih bercampur aduk dengan asset pribadi.

Kelompok usaha eks PNPM ini awalnya adalah para pelaku usaha yang sudah menjalankan aktifitas bisnisnya lebih dari 4 tahun dengan menggunakan dana bergulir melalui PNPM, dan sejak akhir tahun 2014 program ini ditutup oleh pemerintah, maka selanjutnya operasionalisasi diserahkan kepada UPT (Unit Pengelola Teknis) hingga saat ini, dan rata-rata dana yang dikelola UPT ini untuk kabupaten bintan setiap kecamatan rata-rata diatas 1 milyar rupiah.

Dalam pelaksanaannya pinjaman yang digulirkan ini diberikan kepada kelompok yang beranggotakan antara 5-10 orang, namun tanggungjawab dana tersebut adalah anggota masing-masing kelompok yang meminjam. Agar pengembalian dapat diawasi dengan baik maka tugas ketua kelompok yang akan mengkoordinasikan dengan cara mengumpulkan dan menyetor ke UPT. Setiap kelompok yang masuk dalam kategori lancar dalam pengembaliannya (tidak menunggak) maka biasanya akan diberikan insentif dan disebut Insentif Pembayaran Tepat Waktu (IPTW).

Fasilitas atau sarana dan prasarana yang dimiliki oleh kelompok usaha eks
PNPM ini masih cukup memadai dan dapat dikembangkan lagi, dari beberapa kelompok yang ada sudah pernah mendapatkan bimbingan dari pemerintah daerah berupa pembuatan kemasan produk sehingga tampilannya bisa lebih menarik perhatian konsumen. Namun dari sisi yang lain seperti manajerialnya termasuk pemasaran produk masih sangat minim. Oleh karena itu perlu adanya pendampingan dan pelatihan dalam hal tersebut di atas melalui dana hibah Dipa Universitas Maritim Raja Ali Haji dalam bentuk pengabdian masyarakat.

\section{METODE}

Metodologi pelaksanaan dalam pengabdian pada masyarakat ini dibagi menjadi 3 (tiga) tahap yaitu tahap awal, tahap pelaksanaan dan tahap akhir. Pada tahap awal dilaksanakan observasi, dan wawancara secara langsung dengan para pelaku usaha dan aparat pemerintah setempat seperti ketua RW dan pihak Kelurahan, hal ini bertujuan untuk mengetahui gambaran masyarakat setempat dan untuk mengetahui permasalahan/kendala yang dihadapi oleh pelaku usaha.

Tahap kedua adalah tahap pelaksanaan berupa: (1) pelatihan motivasi kewirausahaan, Pada tahap ini, metode yang digunakan adalah berbagi pengalaman dengan para pelaku usaha. Baik pengalaman sukses dalam menjalankan usaha, pengalaman yang sedang merintis usaha, dan pengalaman yang gagal dalam melakukan usaha. Dengan adanya sharing session ini, diharapkan para peserta dapat mengambil pembelajaran dari setiap pengalaman yang dialami oleh para pelaku usaha; (2) pelatihan pembukuan keuangan sederhana yang dapat diaplikasikan oleh pelaku usaha kecil dan mikro, hal ini bertujuan untuk meningkatkan keterampilan dan pengetahuan mengenai manajemen keuangan usaha agar tidak tercampur antara keuangan keluarga dengan 
keuangan usaha, melalui pencatatan keuangan pelaku usaha dapat mengetahui perkembangan usahanya.

Tahap yang terakhir adalah tahap monitoring. Pada tahap ini, dilakukan metode coaching, dimana para peserta pelatihan menunjukkan hasil pencatatan keuangannya dengan menceritakan hambatan dan kesulitan yang dihadapi dalam melakukan proses pencatanan. Selain pencatatan keuangan, para peserta pelatihan juga diharapkan membagi rencana strategis usaha dalam jangka waktu menengah untuk menunjukkan inovasi-inovasi yang akan dilakukan yang dapat meningkatkan daya saing usaha.

\section{HASIL DAN PEMBAHASAN}

\section{Solusi}

Keberdayaan ekonomi masyarakat merupakan perwujudan peningkatan harkat dan martabat lapisan masyarakat untuk melepaskan diri dari perangkap kemiskinan dan keterbelakangan. Langkah ini menjadi bagian dalam meningkatkan kemampuan dan peningkatan kemandirian ekonomi masyarakat. Pemberdayaan ekonomi masyarakat membutuhkan partisipasi aktif dan kreatif. (Basith, 2012).

Konsep kesejahteraan sosial atau kesejahteraan kelompok bagaimanapun bukan sesuatu yang mudah. Berbagai interpretasi subjektif pada konsep ini tidak cukup berarti karena masyarakat tidak dapat dipandang sebagai sebuah organ yang mempunyai pikiran sebagaimana individu didalam masyarakat. Karena pengukuran kesejahteraan social merupakan sesuatu yang tidak mungkin sehingga kita dapat membandingkan kesejahteraan sosial di dalam situasi yang berbeda melalui media pilihan sosial. Pilihan individu mungkin dikatakan sebagai kesejahteraan individu sebab itu pilihan sosial diturunkan dari pilihan-pilihan individu. Kita mungkin dengan mudah mendefinisikan kesejahteraan sosial sebagai penjumlahan dari seluruh kepuasan individu didalam masyarakat. (Sasongko dan Siswoyo, 2013).

Kelompok Usaha Ekonomi Masyarakat adalah sebuah kelompok yang mempunyai kegiatan di bidang ekonomi yang dilaksanakan oleh rumah tangga untuk meningkatkan pendapatan, menciptakan lapangan kerja dan ketahanan pangan masyarakat berbasis sumber daya local. Kegiatan usaha ekonomi produktif merupakan kegiatan pemberdayaan masyarakat dengan memberikan bantuan penguatan modal pinjaman usaha untuk kegiatan ekonomi, sehingga diharapkan mampu meningkatkan ketersediaan panganbagi rumah tangga rawan pangan/miskin di perdesaan.

Unit Pengelola Kegiatan (UPK) PNPM Mandiri Perdesaan dan Perkotaan merupakan lembaga keuangan yang mempunyai kegiatan memberikan pinjaman kepada setiap masyarakat yang ada di perdesaan, tujuan di dalam memberikan dana tersebut adalah untuk meningkatkan modal usaha yang mereka jalani agar usaha dapat berkembang secara maksimal, pinjaman modal yang dapat diberikan dengan rentang $\mathrm{Rp}$ 5.000.000,- sampai dengan Rp 15.000.000,- tergantung kebutuhan usaha yang mereka miliki. Pinjaman tersebut tidak membutuhkan agunan seperti yang dilakukan oleh lembaga keuangan seperti perbankan.

Pelaksanaan kegiatan yang dilakukan oleh UPK di provinsi kepulauan riau sudah berjalan antara 8 sampai 14 tahun tergantung pada pemekaran kecamatan, dengan pengelolaan anggaran dari 1,7 milyar sampai dengan 5 milyar rupiah perkecamatan. Setiap kecamatan di provinsi kepulauan riau memiliki UPK dengan tujuan untuk memberikan pinjaman modal usaha kepada setiap kaum perempuan yang berada di lokasi perdesaan agar dapat mengembangkan usaha dalam mencukupi kebutuhan hidup 
mereka dan dapat membantu suami di dalam menjalani kehidupan keluarga.

\section{Target}

Peningkatan ekonomi masyarakat dan keluarga tak terlepas dari kerja keras yang mereka jalani sehari-hari baik usaha di bidang pertanian, peternakan, perikanan dan home industri, setiap Kecamatan di wilayah Provinsi Kepulauan Riau masing-masing memiliki Unit Pengelola Kegiatan (UPK) dari Program Nasional Pemberdayaan Masyarakat Mandiri Peredesaan yang masing Modalnya berbeda-beda sesuai kebutuhan pengelolaan pinjaman didalam masyarakat, UPK memberikan pinjaman langsung kepada masyarakat untuk meningkatkan Usaha Ekonomi Masyarakat, sistem penyaluran dana tersebut diwajibkan setiap masyarakat untuk membentuk Kelompok yang berguna untuk mempercepat informasi yang akan diberikan oleh UPK maupun Pemerintah baik Pemerintah Daerah maupun Pemerintah Kecamatan.

Persoalan umum yang masih menghantui UKM di Kabupaten Bintan adalah permodalan dan pemasaran, sehingga dengan berakhirnya program PNPM secara nasional tidak lantas menghentikan perputaran modal pinjaman. Jadi peran UPK sebagai pihak yang bertanggungjawab untuk memutar dana eks PNPM menjadi sangat penting, sehingga pertumbuhan dan perputaran ekonomi tetap ada.

Selain itu tumbuh dan berkembangnya UKM di Kabupaten Bintan ini katena menjadi salah satu tujuan wisata baik kuliner, maupun wisata belanja. Akibatnya perkembangan disektor ini pun menjadi surga bagi UKM untuk terus mengembangkan produknya mulai dari industri makanan dan minuman, home industry dan berbagai varian produk lainnya khas Kabupaten Bintan. Apabila geliat di sektor UKM ini terus meningkat, maka akan berbanding dengan peningkatan PAD baik dari sektor jasa maupun dari sektor lainnya.

Dalam pengembangan UKM persoalan yang paling sering muncul adalah masalah permodalan dan pemasaran. Permodalan dasar utamanya yaitu karena sistem akuntansi yang belum diterapkan, dikarenakan UKM banyak mengalami kendala dalam pembuatannya, yaitu minimnya ilmu yang dimiliki tentang sistem akuntansi dan hal itu merupakan kendala sebagian besar yang dihadapi oleh beberapa UKM, dengan kata lain, tidak mengerti harus bagaimana, apa yang harus dipersiapkan, dan bagaimana menerapkannya, sehingga yang menjadi target dalam kegiatan ini adalah para pelaku usaha yang tergabung dalam kelompok usaha ekonomi masyarakat yang menggunakan modal kerjanya dari Eks PNPM yang saat ini dikelola oleh UPK (unit pelaksana kegiatan) yang ada di setiap kecamatan.

\section{Hasil Yang Dicapai}

Hasil yang sudah dicapai dalam pengabdian ini adalah :

a. Memberikan pendampingan dalam rangka meningkatkan manajemen wirausaha bagi kelompok usaha ekonomi masyarakat eks PNPM yang ada di Kelurahan Toapaya Asri, Kecamatan Toapaya, Kabupaten Bintan.

b. Memberikan wacana dan penjelasan kepada kelompok usaha ekonomi masyarakat eks PNPM dalam pengabdian ini bagaimana cara meningkatkan manajemen wirausaha melalui usaha yang sudah dijalankan selama ini, yaitu;

1. Membuat perencanaan terhadap usaha yang dijalankan, adalah tahapan yang sangat penting untuk menjalankan kegiatan usaha dengan membuat perencanaan yang matang, setidaknya mempunyai gambaran seperti apa hasil usaha pada bulan berikutnya. Dengan adanya gambaran hasil 
yang diharapkan maka akan tergambar pula bagaimana cara untuk mewujudkannya, seperti berapa target penjualan yang harus dicapai, bagaimana cara melakukan penjualan agar targetnya tercapai, serta bagaimana melakukan efisiensi biaya untuk menekan cost untuk mendapatkan laba yang maksimal.

2. Bahwa pada setiap cost yang dikeluarkan haruslah memberikan hasil atau imbalan yang lebih besar dari cost yang dikeluarkan sehingga kelebihan tersebut dapat dikategorikan sebagai laba dari sebuah usaha yang dijalankan. Itulah sebabnya agar margin menjadi tinggi maka efisiensi dalam sebuah usaha wajib dilaksanakan karena makin tinggi efisiensi yang dilakukan pada setiap kegiatan usaha akan memberikan hasil secara maksimal. Selain itu kelompok usaha seharusnya dapat mengetahui berapa cost sesungguhnya yang telah dikeluarkan. Dengan mengetahui cost yang sesungguhnya (real cost) maka kelompok usaha akan dapat mengetahui harga pokok dari produk yang dihasilkan.

3. Pemasaran, membantu kelompok usaha dalam memasarkan/ mengenalkan produknya agar lebih dikenal lagi oleh masyarakat luas, selain masyarakat di lingkungan tempat tinggal kelompok usaha, dengan cara memanfaatkan media sosial yang ada. (WhatsApp, Line, BB, Facebook). Promosi dengan cara ini sangat mudah dan bisa dikendalikan langsung setiap saat oleh kelompok usaha.

4. Selain itu kelompok usaha juga membuatkan banner kecil sebagai media promosi. Karena setiap anggota kelompok jenis usahanya tidak sama, maka banner sebaiknya dibuat sendiri-sendiri. Banner ini bertujuan untuk mempermudah customer mencari lokasi sehingga bisa membantu mempromosikan mengenai produk apa saja yang dijual.

c. Penyusunan Laporan Keuangan serta membantu para peserta membuat laporan keuangan, oleh karena latar belakang usaha mereka yang berbeda-beda, maka dalam pelatihan ini menggunakan contoh usaha yang bergerak dalam bidang produksi kerupuk ikan, dan dari pemahaman ini diharapkan akan dapat diterapkan pada usaha mereka masing-masing. Secara umum kelompok usaha mengerti tentang konsep laba dan rugi, di mana untuk mendapatkan laba maka penjualan haruslah lebih besar dari harga pokoknya dan beban-beban yang sudah dikeluarkan selama periode tersebut. Meraka juga dijelaskan tentang aset tetap yang tidak bisa dibebankan sekaligus, namun pembebanannya melalui penyusutan aset tetap. Dalam melakukan penyusutan aset tetap maka data yang harus tersedia adalah : 1) harga perolehan aset tetap; 2) masa manfaat dari aset tetap tersebut; 3) metode penyusutan yang digunakan (umumnya adalah metode garis lurus)

d. Penghitungan penjualan paling minimal agar usaha tidak mengalami kerugian. Sebagian besar pelaku usaha tidak bisa menentukan berapa jumlah penjualan paling minimal agar usaha tidak mengalami kerugian, dan mereka cukup berpendapat bahwa yang penting hasil produksi terjual habis. Padahal produk yang habis terjual belum tentu akan mengalami laba, apalagi kalau harga jualnya sama atau lebih rendah dari harga pokoknya sudah dapat dipastikan bahwa usaha akan 
mengalami kerugian. Oleh karena itu para kelompok usaha harus dapat menentukan penjualan minimal
1. Adanya pemahaman yang diperoleh oleh pelaku usaha, dimana pada materi yang

Tabel 1 Prosentase Pencapaian Kegiatan Pengabdian

\begin{tabular}{|c|l|c|}
\hline No & \multicolumn{1}{|c|}{ Uraian } & Presentase \\
\hline 1. & $\begin{array}{l}\text { Membantu dalam pelatihan penyusunan laporan keuangan, } \\
\text { sehingga pelaku usaha dapat mengetahui dengan tepat apakah }\end{array}$ & $\mathbf{1 0 0 \%}$ \\
\hline 2. & $\begin{array}{l}\text { Membantu pelaku usaha dalam menghitung harga pokok } \\
\text { produksi secara benar, sehingga dapat mengukur dengan pasti } \\
\text { jualnya }\end{array}$ & $\mathbf{1 0 0 \%}$ \\
\hline 3. & $\begin{array}{l}\text { Membantu pelaku usaha untuk menentukan penjualan paling } \\
\text { minimal sehari atau sebulan bergantung pada periodesasi laporan } \\
\text { keuangan yang disusun, hal ini akan sangat membantu pelaku } \\
\text { usaha untuk menjaga agar jangan usaha yang dijalankan menjadi } \\
\text { rugi. }\end{array}$ & $\mathbf{1 0 0 \%}$ \\
\hline
\end{tabular}

secara sederhana melalui laporan laba rugi, tanpa harus menghitung melalui analisa ROI, Break Event Point, dan lain-lain. Pada pelatihan ini peserta selain diajarkan bagaimana cara menyusun laporan laba rugi dari contoh transaksi usaha kerupuk ikan, mereka juga diajarkan bagaimana menentukan penjualan paling minimal untuk menjaga agar usaha tidak mengalami kerugian. Selain itu para pelaku usaha harus mulai terbiasa dengan target penjualan, di mana dengan beraninya membuat target, maka segala sesuatunya menjadi lebih berkembang, belajar dan berdisiplin yang baik dan benar. Dengan demikian maka usaha akan menjadi berkembang sebagaiman yang diharapkan oleh semua pelaku suaha.

e. Realisasi hasil pendampingan manajemen wirausaha, pembuatan Laporan Keuangan Realisasi yang didapat dari pendampingan dan pembinaan kepada kelompok usaha eks PNPM ini adalah ini adalah : diberikan dilengkapi dengan latihan-latihan yang sangat sederhana sehingga mudah untuk dipahami oleh seluruh peserta. Walaupun bentuk usaha yang mereka lakukan berbeda satu sama lain, namun dengan adanya pemahaman dasar pembukuan ini akan dapat diaplikasikan secara langsung dengan usaha mereka.

2. Salah satu yang menjadi persoalan penting dalam menjalankan usaha adalah informasi mengenai harga pokok produksi (HPP), di mana dengan mengetahui perhitungan HPP ini akan memudahkan para pelaku usaha untuk dapat memainkan harga jualnya, dapat menentukan berapa margin yang diharapkan sehingga dapat terhindar dari kerugian. Dengan demikian para pelaku usaha ini sudah bisa memahami bagaimana cara menghitung HPP dengan benar.

3. Pada pelatihan ini kepada peserta juga diajarkan bagaimana cara 
menghitung dan menentukan penjualan paling minimal yang harus dilakukan agar usaha tidak mengalami rugi, hal sangat perlu dilakukan oleh pelaku usaha mengingat sebagian besar para pelaku usaha tidak memperhatikan dan tidak tahu bagaimana cara menentukan penjualan paling minimal tersebut. Ada beberapa syarat yang harus dipenuhi dalam menghitung penjualan paling minimal ini, yaitu tersedianya : a. Data mengenai Harga Pokok Penjualan, b. Data mengenai Harga Jual

Selanjutnya hanya dengan merubah unit penjualan baik di total penjualan maupun di harga pokoknya, maka otomatis pada posisi Laba atau Rugi angkanya juga akan berubah, kita hanya mencari angka laba atau rugi sama dengan nol atau mendekati nol.

Dengan mengetahui penjualan paling minimal ini para pelaku usaha sudah bisa membuat suatu perencanaan penjualan dengan tepat, membuat strategi-strategi dalam meningkatkan penjualan, atau mungkin merekrut karyawan yang khusus untuk memasarkan produk. Strategi seperti ini sangat diperlukan untuk membesarkan usaha dan sangat dimungkinkan untuk melakukan diversifikasi produk, dan bila hal ini sudah tercapai maka langkah selanjutnya yang dapat dilakukan adalah : a. Menambah modal kerja untuk menaikkan produksi atau membuat produk yang baru b. Menambah modal kerja bisa dari dana sendiri atau melakukan pinjaman kepada pihak ketiga (UPT atau Bank) c. Hindari berurusan dengan pemodal/kreditur yang tidak legal karena akan semakin memberatkan pelaku usaha, dimana pembebanan bunga pinjaman yang sangat tinggi dan tidak realistis dengan hasil yang akan diterima.

Tahapan pelaksanaan pengabdian yang sudah dilakukan sampai saat ini adalah pada tahapan: 1) Membantu dalam pelatihan penyusunan laporan keuangan, sehingga pelaku usaha dapat mengetahui dengan tepat apakah usaha mereka mengalami laba atau rugi pada periode tertentu, 2) Membantu pelaku usaha dalam menghitung harga pokok produksi secara benar, sehingga dapat mengukur dengan pasti berapa margin yang akan diperoleh dibandingkan dengan harga jualnya 3) Membantu pelaku usaha untuk menentukan penjualan paling minimal sehari atau sebulan bergantung pada periodesasi laporan keuangan yang disusun, hal ini akan sangat membantu pelaku usaha untuk menjaga agar jangan usaha yang dijalankan menjadi rugi.

Hasil yang diharapkan pada pelatihan ini adalah adanya kejelasan mengenai informasi usaha mendapatkan laba atau rugi dan bagaimana mengatasi bila usaha mengalami rugi, adanya kejelasan mengenai penentuan harga pokok penjualan dan adanya kejelasan mengenai berapa penjualan paling minimal yang harus dilakukan agar usaha tidak mengalami rugi.

\section{Evaluasi Yang Dilakukan Kepada Kelompok usaha :}

Penyusunan Laporan Keuangan 
Setiap usaha diharapkan mempunyai laporan keuangan untuk menganalisis kinerja keuangan sehingga dapat memberikan informasi tentang posisi keuangan, kinerja perusahaan yang bermanfaat bagi pengguna laporan keuangan dalam rangka membuat keputusan-keputusan ekonomi serta menunjukkan pertanggungjawaban yang dihadapi UKM, antara lain rendahnya pendidikan dan kurangnya pemahaman pelaku UKM tersebut dalam bidang akuntansi. Biasanya pembukuan UKM masih dilakukan dengan cara-cara sederhana, dan malah tidak sedikit pelaku usaha menganggap dengan mencatat transaksi tunai ke dalam buku kas, sudah menyelenggarakan pembukuan, padahal

Tabel 2 Hasil Pencapaian Pengabdian Masyarakat

\begin{tabular}{|c|c|c|c|c|}
\hline No & URAIAN & SEBELUM & SESUDAH & $\begin{array}{l}\text { CAPAI } \\
\text { AN }\end{array}$ \\
\hline 1 & $\begin{array}{l}\text { Membantu dalam pelatihan } \\
\text { penyusunan laporan } \\
\text { keuangan, sehingga pelaku } \\
\text { usaha dapat mengetahui } \\
\text { dengan tepat apakah usaha } \\
\text { mereka mengalami laba atau } \\
\text { rugi pada periode tertentu }\end{array}$ & $\begin{array}{l}\text { Menggunakan } \\
\text { cara lama } \\
\text { yaitu hanya } \\
\text { mencatat } \\
\text { transaksi tunai } \\
\text { pada buku kas }\end{array}$ & $\begin{array}{l}\text { Sudah dapat } \\
\text { menyusun laporan } \\
\text { keuangan berupa } \\
\text { Laporan Laba Rugi } \\
\text { dan Neraca dari } \\
\text { aktifitas selama } \\
\text { sebulan }\end{array}$ & $100 \%$ \\
\hline 2 & $\begin{array}{l}\text { Membantu pelaku usaha } \\
\text { dalam menghitung harga } \\
\text { pokok produksi secara benar, } \\
\text { sehingga dapat mengukur } \\
\text { dengan pasti berapa margin } \\
\text { yang akan diperoleh } \\
\text { dibandingkan dengan harga } \\
\text { jualnya }\end{array}$ & $\begin{array}{l}\text { Belum dapat } \\
\text { menghitung } \\
\text { harga pokok } \\
\text { penjualan dari } \\
\text { usaha yang } \\
\text { dijalankan }\end{array}$ & $\begin{array}{l}\text { Sudah dapat } \\
\text { menghitung harga } \\
\text { pokok penjualan per } \\
\text { unit untuk usaha } \\
\text { kerupuk ikan dalam } \\
\text { periode satu bulan }\end{array}$ & $100 \%$ \\
\hline 3 & $\begin{array}{l}\text { Membantu pelaku usaha } \\
\text { untuk menentukan penjualan } \\
\text { paling minimal sehari atau } \\
\text { sebulan bergantung pada } \\
\text { periodesasi laporan keuangan } \\
\text { yang disusun, hal ini akan } \\
\text { sangat membantu pelaku } \\
\text { usaha untuk menjaga agar } \\
\text { jangan usaha yang dijalankan } \\
\text { menjadi rugi. }\end{array}$ & $\begin{array}{l}\text { Belum dapat } \\
\text { menentukan } \\
\text { penjualan } \\
\text { paling } \\
\text { minimal } \\
\text { (break event) } \\
\text { dari usaha } \\
\text { yang } \\
\text { dijalankan }\end{array}$ & $\begin{array}{l}\text { Sudah dapat } \\
\text { menentukan } \\
\text { penjualan paling } \\
\text { minimal (break } \\
\text { event) dari usaha } \\
\text { yang dijalankan } \\
\text { untuk kegiatan } \\
\text { produksi selama satu } \\
\text { bulan }\end{array}$ & $100 \%$ \\
\hline
\end{tabular}

manajemen atas penggunaan sumber daya yang dipercayakan kepada mereka. Namun nyatanya praktek akuntansi keuangan pada Usaha Kecil dan Menengah (UKM) masih sangat rendah.

Dari hasil survey yang pernah dilakukan penulis, masalah kurangnya kemampuan pelaku UKM dalam bidang pengelolaan usaha juga termasuk kendala fase itu baru dimulainya pembukuan bila dilihat dari siklus akuntansi.

Semakin berkembangnya usaha, menuntut UKM untuk berhubungan dengan pihak eksternal perusahaan. Misalnya untuk meningkatkan pendanaan UKM akan berhubungan dengan pihak bank/ lembaga keuangan lainnya. 
Pihak bank/ lembaga keuangan tersebut biasanya akan mensyaratkan laporan keuangan untuk menilai kelayakan kredit dari UKM. Demikian juga ketika UKM akan mengikuti lelang pengadaan barang maupun jasa yang diadakan oleh pihak rekanan, pihak rekanan biasanya akan meminta laporan keuangan sebagai syarat kelengkapan administratif. Dengan demikian semakin berkembangnya usaha, menuntut UKM untuk menyediakan laporan keuangannya dengan baik sesuai standar yang berlaku.

\section{Perhitungan Harga Pokok Penjualan}

Pengertian Harga pokok penjualan (HPP) adalah jumlah semua pengeluaranpengeluaran langsung atau tidak langsung yang berhubungan dengan perolehan, penyiapan dan penempatan barang agar
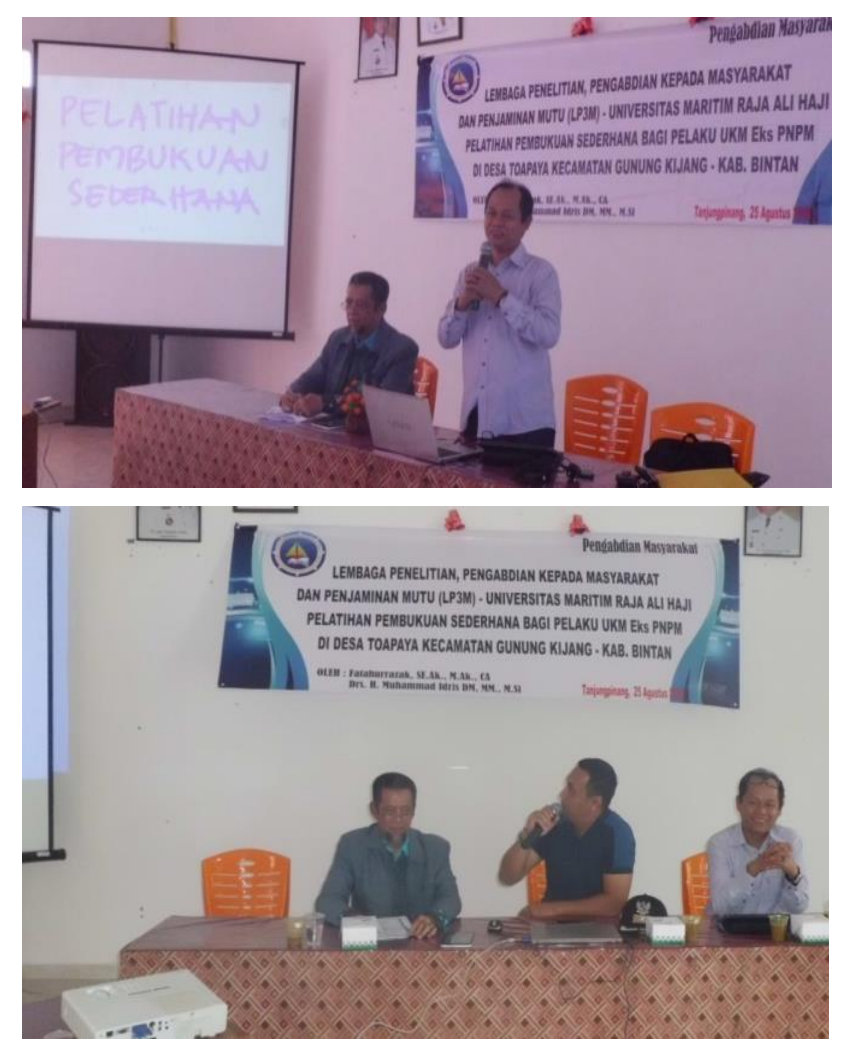

Gambar 1 Kegiatan Pengabdian Kepada Masyarakat

dapat dijual. Dengan istilah lain dapat didefinisikan bahwa HPP adalah harga yang harus dibayar untuk memperoleh suatu barang, dalam prakteknya untuk usaha dagang harga pokok penjualan terdiri dari harga faktur ditambah biaya

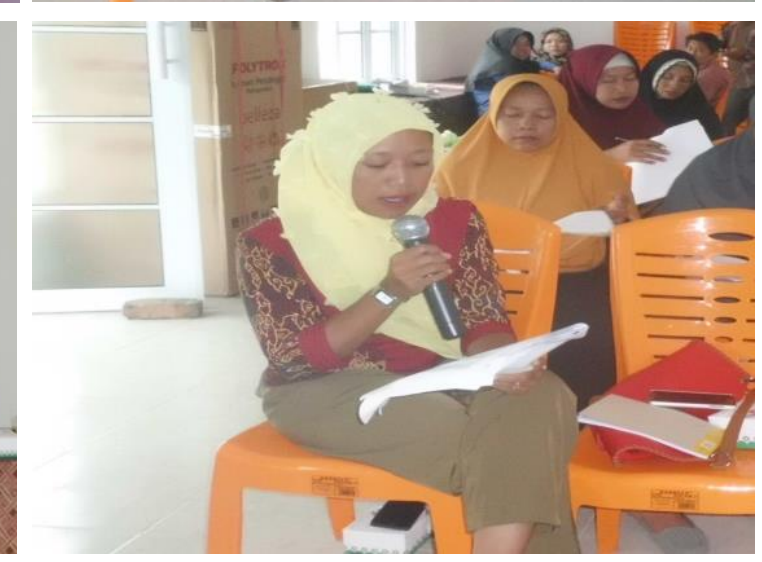

angkut, sementara untuk pabrikasi ditambah biaya produksinya.

Usaha yang telah dibuat tentunya ingin berkembang dan terus berkembang serta terus menjaga kelangsungan hidupnya, untuk itu pihak pelaku usaha perlu membuat kebijakan yang mengacu pada terciptanya efisiensi dan efektivitas kerja.

Kebijakan tersebut dapat berupa penetapan harga pokok penjualan, yaitu dengan cara menekan biaya produksi serendah mungkin namun tetap menjaga kualitas dari barang atau produk yang dihasilkan, sehingga harga pokok produk satuan yang dihasilkan oleh pelaku usaha lebih rendah dari yang sebelumnya.

Kebijakan seperti ini sangat bermanfaat bagi entitas usaha untuk menetapkan harga jual yang tepat dengan laba yang ingin diperoleh pelaku usaha,

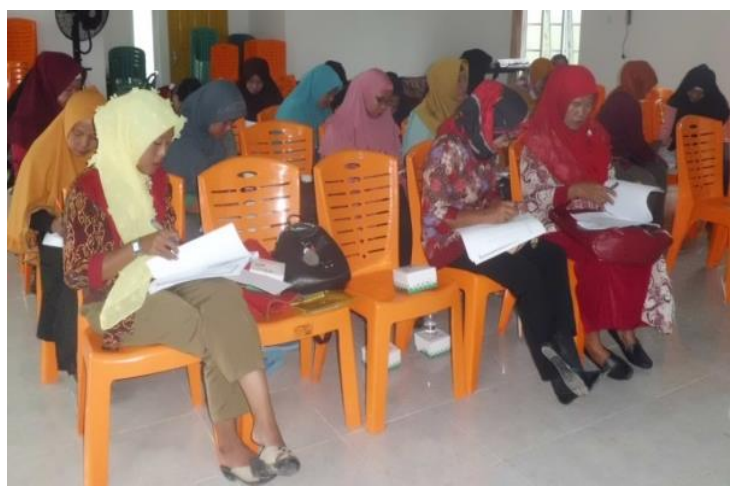

sehingga pelaku usaha tersebut dapat bersaing dengan pelaku usaha lainnya yang memproduksi produk sejenis. Hal ini tentunya tidak terlepas dari tujuan didirikannya usaha yaitu agar modal yang ditanamkan dan dipinjam dalam 
kelompok usaha dapat terus berkembang atau dengan kata lain mendapatkan laba semaksimal mungkin.

Kesalahan dalam perhitungan harga pokok penjualan dapat mengakibatkan penentuan harga jual pada suatu perusahaan menjadi terlalu tinggi atau terlalu rendah. Kedua kemungkinan tersebut dapat mengakibatkan keadaan yang tidak menguntungkan bagi pelaku usaha, karena dengan harga jual yang terlalu tinggi dapat mengakibatkan produk yang ditawarkan akan sulit bersaing dengan produk sejenis yang ada di pasar, sebaliknya jika harga jual produk terlalu rendah akan mangakibatkan laba yang diperoleh rendah pula, jadi menghitung harga pokok penjualan adalah hal yang wajib bagi setiap pelaku usaha.

\section{Perhitungan Penjualan Paling Minimal (Break Event)}

Break Even Point (BEP) adalah titik di mana suatu perusahaan atau bisnis dalam keadaan belum memperoleh keuntungan, namun tidak pula merugi. BEP juga dapat diartikan sebagai sebuah analisis untuk menentukan dan mencari jumlah barang atau jasa yang harus dijual kepada konsumen pada harga tertentu guna menutupi biaya-biaya yang timbul dan memperoleh keuntungan.

BEP juga bisa disebut sebagai suatu keadaan di mana dalam operasi perusahaan, perusahaan tersebut tidak mendapatkan laba dan juga tidak mengalami kerugian. BEP memang dipakai untuk mengetahui apakah perusahaan mencapai BEP atau tidak. Akan tetapi analisa BEP juga bisa dimanfaatkan untuk mengetahui berbagai tingkat volume penjualan dan hubungannya dengan kemungkinan mendapat laba menurut tingkat penjualan yang bersangkutan.

Analisis BEP ini digunakan untuk mengetahui seberapa sukses manajemen perusahaan dalam mencapai target penjualan yang telah ditetapkan. Karena sangat penting tidak heran bila banyak yang mencari tahu cara menghitung BEP.

Analisis BEP mempunyai beberapa fungsi yang bisa kita manfaatkan. Antara lain:

a) Mengetahui jumlah penjualan minimum yang harus dipertahankan supaya perusahaan tidak mengalami kerugian. Jumlah penjualan minimum artinya adalah jumlah produksi minimum yang harus dibuat oleh perusahaan.

b) Menentukan jumlah penjualan yang harus dicapai agar memperoleh laba yang telah direncanakan. Bisa juga diartikan bahwa tingkat produksi harus ditetapkan untuk memperoleh laba tersebut.

c) Mengukur dan menjaga agar penjualan dan tingkat produksi tidak lebih rendah dari BEP.

d) Menganalisis perubahan harga jual, harga pokok dan besarnya hasil penjualan atau tingkat produksi.

e) Suatu alat perencanaan penjualan dan sekaligus perencanaan tingkat produksi, supaya perusahaan secara minimal tidak mengalami kerugian.

\section{Luaran Yang Dicapai}

Luaran yang diharapkan melalui IbM yang didanai melalui Dipa Umrah yaitu : Dalam Dipa Pengabdian Pada Masayarakat yang didanai oleh Umrah. Adapun luaran yang dihasilkan dalam bentuk Proseding atau Jurnal ISSN; peningkatan Iptek di masyarakat melalui pengelolaan manajemen pada kelompok usaha sedangkan luaran tambahan produk/barang

\section{KESIMPULAN}

Kesimpulan yang diperoleh dari kegiatan pengabdian ini adalah sedapat mungkin pembinaan yang dilakukan ini dapat berkelanjutan, dan bila memungkinkan menggunakan model percontohan, maksudnya adalah pemerintah daerah membuat suatu model 
pelatihan yang berterusan kepada kelompok usaha tertentu yang dipilih, kemudian setelah mereka mahir maka pembinaan selanjutnya dapat dilakukan pada kelompok yang lain dengan melibatkan kelompok yang sudah mahir. Mereka sebagai contoh yang mencontohkan. Model ini seperti bola salju yang awalnya kecil, namun semakin lama semakin besar sehingga tercipta momentum yang sangat kuat. Hal yang terpenting bagi pelaku usaha ini adalah bagaimana dana yang mereka pinjam dapat diusahakan dengan baik untuk usaha mereka sehingga pinjaman dapat diangsur dan diselesaikan dengan baik, dengan harapan untuk putaran pinjaman periode berikutnya akan mendapat jumlah yang lebih besar lagi. Dengan latar pendidikan yang sudah mereka tempuh akan sangat menentukan bagaimana menata usaha dengan baik secara manajerial

\section{DAFTAR PUSTAKA}

Hery . 2012. Akuntansi Sektor Jasa \& Dagang Untuk Usaha Kecil \& Menengah. Jakarta: Gramedia.

--------, 2013 Akuntansi Dasar 1 dan 2. Jakarta : Grasindo

-------, 2016. Analisis Laporan Keuangan. Jakarta : PT.Gramedia Widiasarana Indonesia

Haryono,Y.A.2011. DasardasarAkuntansi. Edisi 1, STIEYKPN.Yogyakarta

Ikatan Akuntan Indonesia, Standar Akuntansi Keuangan Entitas Mikro Kecil menengah,2016

Rivai, V. (2013). Commercial Bank Management : Manajemen Perbankan Dari Teori Ke Praktik. Edisi 1.Cetakan1. Jakarta: Rajawali Pers.

Sugiyono. 2016. Metode Penelitian Kombinasi (Mixed Methods). Cetakan ke 8. Penerbit Alfabeta Bandung
Fahmi, Irham. 2012. Analisis Laporan Keuangan. Bandung: Alfabeta.

Undang-undang Republik Indonesia No 28 tahun 2007 tentang Perubahan Ketiga atasUndang-Undang No 6 tahun 1983 tentang Ketentuan Umum dan Tata Cara Perpajakan

Diterima : 5 September 2018

Disetujui : 8 November 2018 